vated. The Rev. Dr. B. C. Henry, in a letter dated January 26 , informs me that "the destruction of vegetation about Canton has been very great. The banana plantations are ruined, and the bamboos have suffered. The Aleurites triloba look all shrivelled up, while Begonias, Euphorbias, Crotons and scores of others are simply destroyed." What Dr. Henry reports indicates severer weather at Canton than here, Aleurites triloba leaves being shrivelled up at Canton, while they are here at 300 feet altitude uninjured, but at 600 feet they are affected, and completely destroyed a little higher up the hill.

(23) Accompanying this report are six photographic views which were taken on January 16 showing the ice at various places in the Peak district. It is somewhat difficult to represent ice in photographs, as bright light has much the same effect as ice which owes its white appearance merely to reflected light, but it will be understood that the white in these views is produced by ice.

CHARLES FORD,

Superintendent Botanical and Afforestation Department.

HoN. G. T. M. O'Brien. C. M.G.,

Colonial Secretary, \&c.

The importance of such facts as these in connection with geographical distribution can hardly be overrated. It is customary to compare the range of a plant with the corresponding mean annual temperature. But it is obvious that the exterminating effect of occasional low temperature must override every other condition. An island is often the last refuge of a species not found elsewhere. Such a frost as occurred in Hongkong would erase the Double Cocoa-nut in all probability from the face of creation, if it occurred in the Seychelles. In any case islands are not easily restocked except with littoral vegetations and the trees distributed by carpophagous birds. It seems evident therefore that the geographical distribution of plants may still be influenced by causes which are catastrophic in their nature. Of this, although not from cold, there is already a striking illustration in the simultaneous destruction of the entire forest vegetation which at one time covered the island of Trinidad in the South Atiantic. Mr. Knisht, in the account which he has given in the "Cruise of the Falcon," conjectures that the cause was more probably volcanic than a long drought.

The wave of cold which affected Hongkong (or at any rate the atmospheric conditions which produced it) seems to have been tolerably extended in its range. My friend, Dr. Trimen, writes to me on February 6 from Ceylon:-

"We are having a wonderfully fine and dry time here, with extraordinary cold mornings. Here at Pecadeniya we have been registering at $6 \mathrm{a} . \mathrm{m} .53^{\circ}$ and $54^{\circ} \mathrm{F}$., the lowest ever previously known being a little below $60^{\circ}$. The middle of the day is very hot. Hakgala has been getting frost for the first time on record."

He does not give any dates; but the two exceptional circumstances are sufficiently near together to make it probable that some common cause produced them both.

Royal Gardens, Kew, March 28. W. T. Thiselton-Dyer.

P.S. - Since writing the above I have received from the Colonial Office the accompanying report on the weather of January from the Hongkong Observatory. - $[\mathrm{W}$. T. T. -D.]

The mean temperature was below the average from the I 4 th to the 24 th. The coldest day (air $35^{\circ} \cdot 2$, damp bulb $32^{\circ} \cdot 8$ ) was the r6th. The lowest mean temperature of the damp-bulb thermometer occurred on the 17 th (air $36^{\circ} \cdot 2$, damp bulb $30^{\circ} \cdot 9$ ). Circumstances were anti-cyclonic, with probably abnormally slight decrease of temperature with height. Snow-storms were reported from China to the north and east of the colony. From Macao snow was reported, but that appears to have really consisted of small-sized hail, which fell for four hours. Neither snow nor hail were seen in Hongkong, but the tops of the hills appeared to be covered by snow or hoar-frost. Water exposed in buckets or in pools was several mornings found covered with ice about $\frac{1}{4}$ inch thick, and a few hundred feet above sea-level both the grass and branches of trees, being cooled below the temperature of the air (which did not fall below freezing-point) owing to evaporation and radiation, were encased in unusually clear and transparent ice without any appearance of crystallisation. As far south as the Straits Settlements the cold was felt, but in a less degree. The temperature appears not to have fallen below $70^{\circ}$ in Singapore. At sea strong northerly breezes were

NO. I 223 , VOL. 47] observed during the greatest cold. The colony was sheltered by the mainland, and-only light northerly breezes were registered till the 2oth, when the wind backed to west. It veered to east on the 2 Ist. During the coldest days the pressure was from one to two-tenths of an inch of mercury above the mean. The sky was overcast, but cleared on the evening of the 17 th. Owing to radiation the extreme temperatures occurred after this epoch the lowest air-temperature $32^{\circ} \circ$ about $7 \mathrm{a} . \mathrm{m}$. on the $18 \mathrm{th}$, and the lowest damp-bulb temperature $27^{\circ} .7$ about 2.30 a.m. on the same day.

Hongkong Observatory, February $\mathrm{x}$.

\section{Mr. Preece on Lightning Protection}

IN the recent Presidential Address to the Institution of Electrical Engineers by $\mathrm{Mr}$. Preece, I find the following reference to myself.

"Prof. Oliver Lodge has . . endeavoured to modify our views as to the behaviour of lightning discharges, and as to the form of protectors, but without much success. His views have not received general acceptance, for they are contrary to fact and to experience."

I was quite prepared to laugh at this with the rest, but I find that the general and semi-scientific public are apt to take $\mathrm{Mr}$. Preece's little jokes, of which there are many towards the end of this address, as serious and authoritative statements of scientific fact. And it has been represented to me that unless I take some notice of the above, it may be assumed that I wish silently to withdraw from an untenable position without acknowledging having made a mistake.

Indeed, I have already heen questioned by a scientific worker as to whether I accepted the above statement as in any sense corresponding to truth.

My reply is that so far was I from that attitude, that I did not suppose that the statement was either meant or would be taken seriously.

The broad question of scientific fact is this:-Given an electrostatic charge at high potential, can the potential be reduced to zero most quietly and safely by a good conductor or by a bad one?

The old lightning-rod doctrine (or drain-pipe theory) said, by an extravagantly good one. I say, by a reasonably bad one. It you employ too good a conductor the mean square of current is appallingly strong, and all manner of dangerous oscillations are set up ; whereas in a bad conductor the discharge can be more nearly dead-beat. These oscillations have been experimentally and mathematically demonstrated in a great variety of ways, the unexpected and distinct effects they are able to produce have been displayed, and Messrs. Whittaker have published for me a large book about them.

Some critics have sensibly objected that the book is too big, but I am not aware of any scientific authority who controvert. my position.

If Mr. Preece only means that these views regarding lightning and its dangers are not yet practically accepted by the great British Telegraphic Department, that is, I admit, perfectly true. Oliver LODGe.

\section{The Author of the Word "Eudiometer."}

FOR some time past I have been endeavouring to find out the originator of the name eudiometer, which is now applied to the measuring tubes used in gas analysis, and possibly the result of the search may be of interest to some of the readers of NATURE.

Naturally my first resort was to text-books and dictionaries, but although the derivation of the word is sometimes given, the name of the author is not stated.

I had great hopes that the third edition of the " Encyclopedia Britannica," published in 1797 , would contain the desired information, for the article "Eudiometer" must have been written not long after the invention of the instrument, but it merely calls it " an instrument for observing the purity of the atmospherical air." Descriptions of many forms of eudiometer follow.

The New English Dictionary gives the derivation and the first quotation is " 1777 . De Magellan (title), Glass apparatus for making mineral waters....... with the description of some new Eudiometers"; another is " 1807 . Pepys. Eudiometer in Phil. 